\title{
Amino Acid Derivatives as New Zinc Binding Groups for the Design of Selective Matrix Metalloproteinase Inhibitors
}

\author{
Mariateresa Giustiniano, ${ }^{1}$ Paolo Tortorella, ${ }^{2}$ Mariangela Agamennone, ${ }^{3}$ \\ Antonella Di Pizio, ${ }^{3}$ Armando Rossello, ${ }^{4}$ Elisa Nuti, ${ }^{4}$ Isabel Gomez-Monterrey, ${ }^{1}$ \\ Ettore Novellino, ${ }^{1}$ Pietro Campiglia, ${ }^{5}$ Ermelinda Vernieri, ${ }^{5}$ Marina Sala, ${ }^{5}$ \\ Alessia Bertamino, ${ }^{5}$ and Alfonso Carotenuto ${ }^{1}$ \\ ${ }^{1}$ Dipartimento di Chimica Farmaceutica e Tossicologica, Università di Napoli “Federico II," Via D. Montesano 49, 80131 Napoli, Italy \\ ${ }^{2}$ Dipartimento di Farmacia, Università degli Studi di Bari "Aldo Moro," Via Orabona 4, 70125 Bari, Italy \\ ${ }^{3}$ Dipartimento di Farmacia, Università degli Studi “G. d’Annunzio," Via dei Vestini 31, 66013 Chieti, Italy \\ ${ }^{4}$ Dipartimento di Scienze Farmaceutiche, Università di Pisa, Via Bonanno 6, 56126 Pisa, Italy \\ ${ }^{5}$ Dipartimento di Scienze Farmaceutiche e Biomediche, Università degli Studi di Salerno, Via Ponte don Melillo, 84084 Fisciano, Italy \\ Correspondence should be addressed to Alfonso Carotenuto; alfocaro@unina.it
}

Received 21 December 2012; Accepted 28 January 2013

Academic Editor: Giuseppe De Rosa

Copyright (C) 2013 Mariateresa Giustiniano et al. This is an open access article distributed under the Creative Commons Attribution License, which permits unrestricted use, distribution, and reproduction in any medium, provided the original work is properly cited.

\begin{abstract}
A number of matrix metalloproteinases (MMPs) are important medicinal targets for conditions ranging from rheumatoid arthritis to cardiomyopathy, periodontal disease, liver cirrhosis, multiple sclerosis, and cancer invasion and metastasis, where they showed to have a dual role, inhibiting or promoting important processes involved in the pathology. MMPs contain a zinc (II) ion in the protein active site. Small-molecule inhibitors of these metalloproteins are designed to bind directly to the active site metal ions. In an effort to devise new approaches to selective inhibitors, in this paper, we describe the synthesis and preliminary biological evaluation of amino acid derivatives as new zinc binding groups (ZBGs). The incorporation of selected metal-binding functions in more complex biphenyl sulfonamide moieties allowed the identification of one compound able to interact selectively with different MMP enzymatic isoforms.
\end{abstract}

\section{Introduction}

Matrix metalloproteinases (MMPs) are 23-member zincdependent endopeptidases family involved in the extracellular matrix turnover [1]. Their aberrant regulation has been implicated in tumoral process, where they showed to have a dual role inhibiting or promoting cell growth and survival, angiogenesis and metastasis [2,3] differentiation [4], and inflammation and immune surveillance [5]. Moreover, MMPs are overexpressed in a variety of tumor types, and their overexpression is associated with tumor aggressiveness and poor prognosis [6]. The specific alteration of the MMPs in malignant tissues and their participation in some of the major oncogenic mechanisms have both fuelled interest in the design and evaluation of MMP inhibitors (MMPIs) as anticancer agents $[7,8]$. Generally, the MMPIs design involves peptide or peptidomimetic backbones containing a zinc-binding group (ZBG) able to interact with both the subpockets surrounding the active site $\left(S_{1}\right.$ and $S_{1}^{\prime}, S_{2}^{\prime}$, and $\left.S_{3}^{\prime}\right)$ and the zinc (II) ion present in the catalytic site, respectively $[9,10]$. The greater part of MMPIs research has focused on developing the peptide or peptidomimetic containing a hydroxamic acid as chelating group. Although this design has produced potent inhibitors such as Batimastat [11, 12] and Marimastat [13] (Figure 1), none of these MMPIs has successfully completed clinical trials.

The inability of hydroxamates to produce clinically viable compounds has been attributed to low oral availability, poor in vivo stability, and undesirable side effects associated with these compounds [14]. This has prompted the investigation of a limited number of nonhydroxamate-based MMPIs [15-19]. We present herein the results obtained with a small library 
<smiles>CNC(=O)[C@H](CC(C)C)C(=O)N[C@@H](CSc1cccs1)C(=O)NO</smiles>

Batimastat

(a)

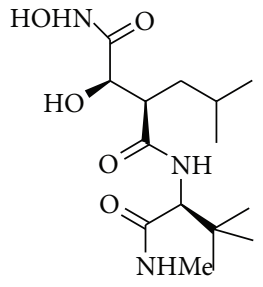

Marimastat

(b)
FIGURE 1: Structures of Batimastat and Marimastat.

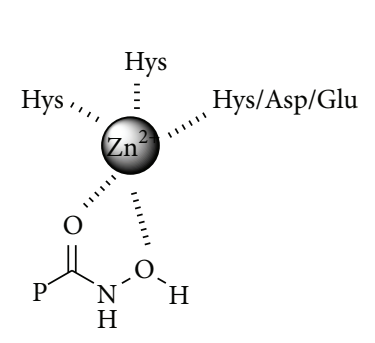

(a)

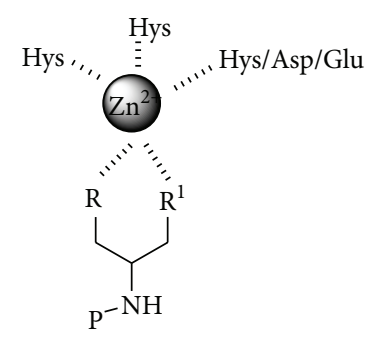

(b)
FIgURE 2: Hypothetical interaction between $\mathrm{ZBG}$ and $\mathrm{Zn}^{2+}$.

of compounds synthesized and tested as potential ZBGs. The compounds were selected on the basis of some similarities to hydroxamates, such as the possibility to form five-member chelates (Figure 2), but with potentially enhanced pharmacokinetic properties such as a better hydrolytic stability and/or proposed increased affinity for the MMP zinc (II).

The designed ligands have a general 2-aminopropane1,3-disubstituted structure which might be visualized as an amino acid derivative with the $\alpha$ carbon atom connected through two $\beta$ carbons to heteroatoms with lone pairs or simply electron availability $\left(\mathrm{R}\right.$ and $\left.\mathrm{R}_{1}\right)$. These functional groups are sulfhydryl $(\mathrm{SH})$, alcohol $(\mathrm{OH})$, imidazole, cyano $(\mathrm{CN})$, and azide $\left(\mathrm{N}_{3}\right)$ which are able to interact as Lewis-base in the coordination of the catalytic zinc ion. Their symmetric and asymmetric combination gave rise to a small ZBGs library (Table 1). The two $\beta$ carbons rotational freedom could allow the chelating groups $\mathrm{R}$ and $\mathrm{R}_{1}$ to orient themselves as better as possible in direction of the zinc ion.

According to the preliminary results of enzymatic inhibition activities, we further synthesized, from the most interesting ligands, a small series of sulfonamide derivatives containing a phenoxyphenyl group. This moiety has been widely used in the design of MMPs inhibitors as side chain of choice able to interact with the enzymatic $S_{1}^{\prime}$ subsite which plays a pivotal role in the determination of inhibition selectivity $[20,21]$. The aims of the current study were to screen a range of nonhydroxamate structures as new ZBGs and to evaluate the enzymatic activity of small molecules designed to interact with the subpocket $S_{1}^{\prime}$ and with the zinc (II) ion present in the catalytic site of MMPs.
TABLE 1: Synthesized ZBGs library.

\begin{tabular}{cccc}
\hline Compounds & & $\mathrm{R}$ & $\mathrm{R}_{1}$ \\
\hline & $\mathbf{1 a}$ & $\mathrm{OH}$ & $\mathrm{OH}$ \\
& $\mathbf{1 b}$ & $\mathrm{CN}$ & $\mathrm{CN}$ \\
& $\mathbf{1 c}$ & $\mathrm{N}_{3}$ & $\mathrm{~N}_{3}$ \\
& $\mathbf{1 d}$ & $\mathrm{SH}$ & $\mathrm{OH}$ \\
& $\mathbf{1 e}$ & Imidazole & $\mathrm{OH}$ \\
& $\mathbf{1 f}$ & $\mathrm{SH}$ & $\mathrm{SH}$ \\
& $\mathbf{1 g}$ & Imidazole & $\mathrm{SH}$ \\
& $\mathbf{1 h}$ & $\mathrm{SH}$ & $\mathrm{CN}$ \\
& $\mathbf{1}$ & $\mathrm{OH}$ & $\mathrm{CN}$ \\
& $\mathbf{1 i}$ & $\mathrm{SH}$ & $\mathrm{N}_{3}$ \\
& $\mathbf{1 j}$ & $\mathrm{OH}$ & $\mathrm{N}_{3}$ \\
& $\mathbf{1 k}$ & Imidazole & $\mathrm{N}_{3}$ \\
& $\mathbf{1 l}$ & &
\end{tabular}

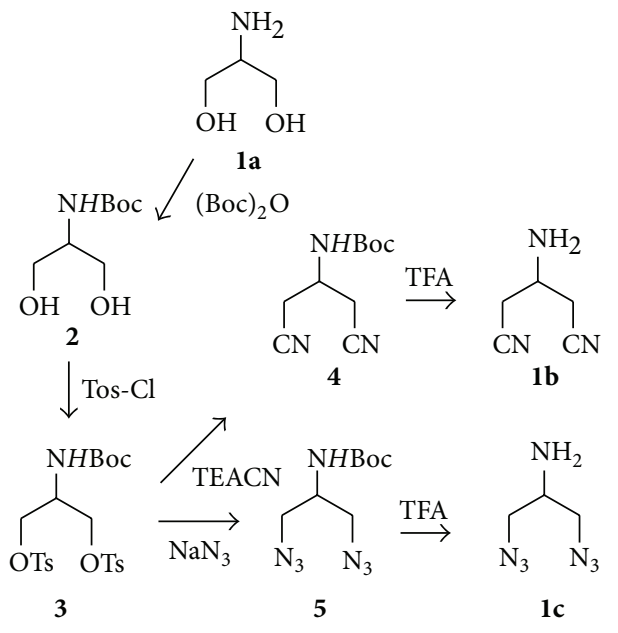

Scheme 1: Synthesis of symmetric ZBGs $\mathbf{1 a}, \mathbf{1 b}$, and $\mathbf{1 c}$.

\section{Chemistry}

The symmetric ligands were prepared starting from serinol (1a) according to synthetic route shown in Scheme 1. After $\mathrm{N}$-Boc-protection, the alcohol groups of $\mathbf{2}$ were activated as ditosylate derivatives in order to undergo nucleophilic substitution with azide and nitrile salts. Thus, displacement of the OTs group with tetraethylammonium cyanide (TEACN) or sodium azide $\left(\mathrm{NaN}_{3}\right)$ in DMF using TEA as base led to 4 and 5, respectively, with $80 \%-82 \%$ yields. The final symmetric derivatives $\mathbf{1 b}$ and $\mathbf{1 c}$ have been obtained after deprotection of 2-amino group using a solution of $25 \%$ TFA in dichloromethane.

The ditosylation reaction was the limiting step in this synthetic strategy, described in the literature using pyridine (py) as solvent [22]. In our case, the treatment of $\mathbf{2}$ with 4toluenesulfonyl chloride in pyridine led to ditosylate derivative 3 in only $2 \%$ yield. A preliminary study of the influence of solvents, reaction time, and reactive/base concentration ratio on this reaction was performed in order to (a) improve yields and mono/ditosylate adduct ratio; (b) facilitate workup procedures; (c) use a less toxic solvent. 


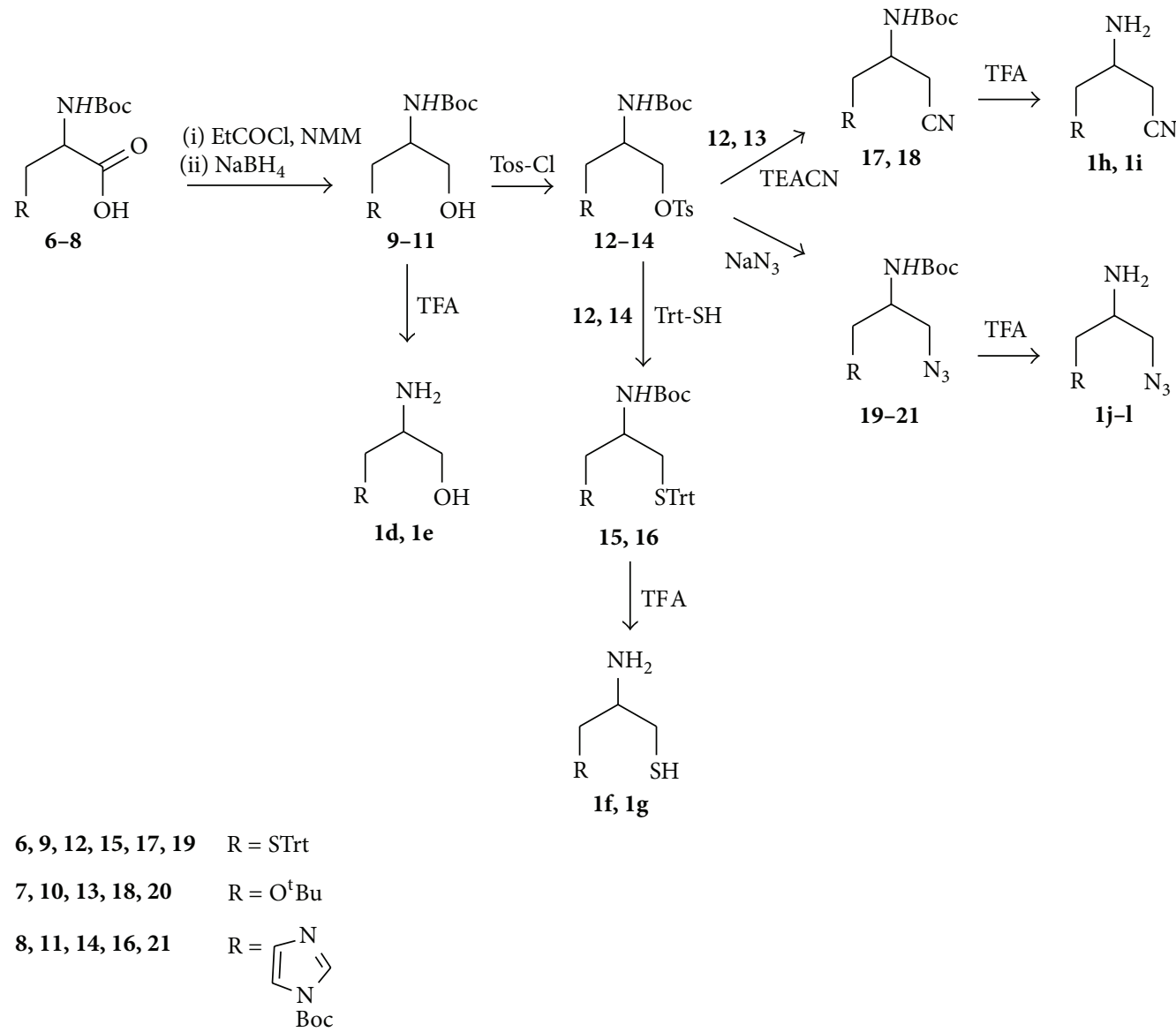

Scheme 2: Synthesis of symmetric (1f) and asymmetric (1d, le, 1g-1l) ZBGs.

TABLE 2: Study on ditosylation reactionof N-Boc-serinol (2).

\begin{tabular}{lccccc}
\hline Entry & Solvents & Reaction time & TsCl:TEA & $\begin{array}{c}\text { Yields } \\
(\%)\end{array}$ & $\begin{array}{c}\text { Mono/di } \\
\text { ratio }\end{array}$ \\
\hline $\mathbf{1}$ & Py & $6 \mathrm{~h}$ & $2.4: 3$ & 29 & $10: 1$ \\
$\mathbf{2}$ & Py & $10 \mathrm{~h}$ & $3: 4$ & 40 & $10: 1$ \\
$\mathbf{3}$ & Py, DMAP cat & $6 \mathrm{~h}$ & $3: 4$ & 31 & $10: 1$ \\
$\mathbf{4}$ & DCM, Py cat & $6 \mathrm{~h}$ & $2.4: 3$ & 53 & $5: 1$ \\
$\mathbf{5}$ & DCM, Py cat & $10 \mathrm{~h}$ & $3: 4$ & 45 & $5: 1$ \\
$\mathbf{6}$ & DCM & $6 \mathrm{~h}$ & $3: 4$ & 55 & $1: 1$ \\
$\mathbf{7}$ & dry DCM & $10 \mathrm{~h}$ & $3: 4$ & 68 & $1: 2$ \\
$\mathbf{8}$ & dry DCM & $10 \mathrm{~h}$ & $2.4: 3$ & 85 & $1: 19$ \\
\hline
\end{tabular}

As shown in Table 2, treatment of 2 with Tos-Cl and TEA in $2.4: 3$ ratio gave the highest yields $(85 \%)$ and better selectivity $(1: 19)$ in the formation of ditosylate derivative 3 using dry dichloromethane as solvent (entry 8). Pyridine or pyridine with dimethylaminopyridine as base catalyst gave low yields with a little percentile of dialkylation product (entries 1, 2, and 3), while DCM as solvent was more effective without base catalyst (entries 6, 7, and 8 versus entries 4 and $5)$.
The symmetric and asymmetric ligands, $\mathbf{l f}$ and $\mathbf{1 d}, \mathbf{l e}$, and $\mathbf{1 g - 1 1}$, respectively, were prepared according to the synthetic route shown in Scheme 2.

Protected amino acids Boc-Cys(Trt)-OH (6), Boc$\mathrm{Ser}(\mathrm{OtBu})-\mathrm{OH}(7)$, and Boc-His(Boc)-OH (8) were reduced to corresponding alcohols (9-11) using sodium borohydride as we previously described [23]. Treatment of hydroxy derivatives 9 and $\mathbf{1 1}$ with 20\% TFA/DCM gave directly the corresponding final asymmetric ligands $\mathbf{1 d}$ and $\mathbf{l e .}$ Analogously, reaction of hydroxyl derivatives with Tos-Cl in DCM and TEA led to tosylate intermediates 14-16 which were submitted to nucleophilic substitution reaction with azide and nitrile salts in the previously mentioned conditions to give the corresponding cyano $(\mathbf{1 7 , 1 8})$ and nitrile $(\mathbf{1 9 - 2 1 )}$ derivatives. Loss of protective groups after treatment of intermediates 12-21 with 50\% TFA/DCM solution conduced to final compounds $\mathbf{1 f}-\mathbf{1 1}$.

Finally, the N-substituted phenoxybenzensulfonamide 25a, 25d, and 25e were prepared according to synthetic route of Scheme 3. The sulfonation of diphenylether $\mathbf{2 2}$ with chlorosulfonic acid $\left(\mathrm{ClSO}_{3} \mathrm{H}\right)$ and afterward chlorination with thionyl chloride $\left(\mathrm{SOCl}_{2}\right)$ afforded the key 4phenoxybenzensulfonyl chloride 24 with $95 \%$ overall yields. The coupling of $\mathbf{2 4}$ with $\mathbf{1 a}, \mathbf{1 d}$, and $\mathbf{1 e}$ in DMF and cesium carbonate $\left(\mathrm{Cs}_{2} \mathrm{CO}_{3}\right)$ gave directly the corresponding final compounds in $42 \%-55 \%$ yields. 
<smiles>[R]CC(C[R])NS(=O)c1ccc(Oc2ccccc2)cc1</smiles>

25a, 25d, 25e
TABLE 4: Enzymatic activity of N-substituted phenoxybenzensulfonamide 25a, 25d, and 25e on different MMPs.

\begin{tabular}{|c|c|c|c|c|c|c|}
\hline \multirow{2}{*}{ Com. } & \multirow[t]{2}{*}{$\mathrm{R}$} & \multirow{2}{*}{$\mathrm{R}_{1}$} & \multicolumn{4}{|c|}{$\mathrm{IC}_{50}(\mu \mathrm{M} \pm \mathrm{SD})$} \\
\hline & & & MMP-1 & MMP-2 & MMP-8 & MMP-9 \\
\hline $25 a$ & $\mathrm{OH}$ & $\mathrm{OH}$ & $1030 \pm 160$ & $71 \pm 1.9$ & $98 \pm 8.0$ & $160 \pm 15$ \\
\hline 25d & $\mathrm{SH}$ & $\mathrm{OH}$ & $819 \pm 116$ & $110 \pm 10$ & $9.1 \pm 2.3$ & $12 \pm 4.0$ \\
\hline $25 \mathrm{e}$ & Imidazole & $\mathrm{OH}$ & $480 \pm 30$ & $190 \pm 8.7$ & $330 \pm 21$ & $200 \pm 15$ \\
\hline
\end{tabular}

fluorometric assay, and the obtained $\mathrm{IC}_{50}$ values are summarized in Table 4. Compound 25a exhibited an interesting inhibitory activity on MMP-2 and MMP-8, two enzymatic isoforms characterized by an intermediate and a deep $S_{1}^{\prime}$ subpocket, respectively [25-28]. This compound showed also a good selectivity over MMP-1 which has a shallow $S_{1}^{\prime}$ pocket. The substitution of a hydroxyl with an imidazole group, compound 25e, caused a loss of both potency (except on MMP-1) and selectivity on the enzymes used in this study. The most interesting results were obtained with compound $\mathbf{2 5 d}$. This compound showed a high inhibitory activity on MMP8 and MMP-9 with $\mathrm{IC}_{50}$ values in the micromolar range (10and 13 -fold more potent than 25a, resp.) and maintained a good selectivity over both MMP-2 and MMP-1.

These preliminary results showed a different behaviour of ZBGs when they are introduced into a more complex structure indicating that, in this case, the modulation of selectivity does not depend only on ZBGs [29].

\section{Molecular Modeling}

In order to rationalize the observed activity data, docking calculations of the ZBGs and compounds $25 \mathrm{a}, 25 \mathrm{~d}$, and $25 \mathrm{e}$ were performed on the MMP-2 catalytic domain. Subsequently, they were submitted to a refinement step, thorough minimization of best poses. The applied protocol allowed to correlate predicted and experimental binding energies. It is well known that docking scores hardly correlate with activity data, and to this aim, more accurate calculations are required such as Free Energy Perturbation or Thermodynamic Integration. Among available approaches, Linear Interaction Energy (LIE) represents a good compromise between accuracy and speed of calculations [30, 31]. In this approach, the binding process is represented as the replacement of water molecules solvating a ligand by the protein, using an implicit water model.

LIE generates a custom scoring function calculating the values of alpha, beta, and gamma coefficients of the following equation:

$$
\begin{aligned}
\text { Delta } G= & \text { alpha } *\left(U \mathrm{vdw}_{-} b-U \mathrm{vdw}_{-} f\right) \\
& +\operatorname{beta} *\left(U \text { elec } \_b-U \text { elec }_{-} f\right) \\
& + \text { gamma } *\left(U \operatorname{cav}_{-} b-U \operatorname{cav}_{-} f\right)
\end{aligned}
$$

Compounds 25a, 25d, and 25e were tested against human recombinants MMP-1, MMP-2, MMP-8, and MMP-9 by a 


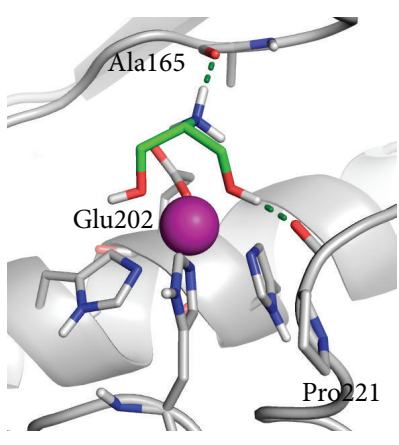

(a)

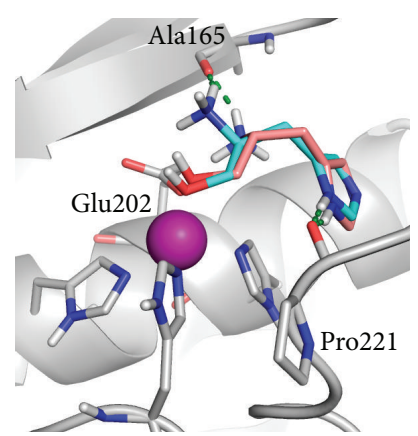

(b)

FIgURE 3: Docked poses of 1a (a) and le in both enantiomeric forms (b) into the MMP-2 active site. MMP-2 is represented as a grey cartoon. Ligands and most relevant residues are depicted as sticks. H-bonds are represented as green dashed lines.

TABle 5: Predicted and calculated binding energy (kcal) for all compounds toward MMP-2.

\begin{tabular}{|c|c|c|c|}
\hline Compound & $\Delta G \exp$ & $\Delta G$ calc (R-model) & $\Delta G$ calc (S-model) \\
\hline $1 a$ & -4.837 & -4.628 & -4.484 \\
\hline lb & -4.428 & -4.734 & -4.619 \\
\hline 1c & $-^{\mathrm{a}}$ & $-^{\mathrm{a}}$ & $-^{\mathrm{a}}$ \\
\hline $1 d R$ & -4.319 & -4.512 & \\
\hline $1 d S$ & -4.017 & & -4.492 \\
\hline le $\mathrm{R}$ & -4565 & -4.395 & \\
\hline le $S$ & & & -4.614 \\
\hline If & -4.333 & -4.538 & -4.592 \\
\hline $\lg R$ & -4.796 & -4.583 & \\
\hline $\lg S$ & 170 & & -4.739 \\
\hline lh R & -4497 & -4.421 & \\
\hline lh S & -4.48 & & -4.303 \\
\hline li R & -4210 & -4.391 & \\
\hline li $S$ & & & -4.379 \\
\hline $1 j \mathrm{R}$ & -4469 & $-^{\mathrm{a}}$ & $-^{\mathrm{a}}$ \\
\hline lj S & & & -4.511 \\
\hline lk R & -4.469 & -4.237 & \\
\hline $1 \mathrm{kS}$ & -4.409 & & -4.513 \\
\hline $11 \mathrm{R}$ & -4524 & -4.624 & \\
\hline $11 S$ & -4.524 & & -4.338 \\
\hline $25 a$ & -5.655 & -5.506 & -5.326 \\
\hline $25 d R$ & -5.396 & -5.349 & \\
\hline $25 d S$ & & & -5.279 \\
\hline 25 e R & -5069 & 5.179 & \\
\hline $25 \mathrm{e} S$ & -5.009 & & -5.378 \\
\hline
\end{tabular}

${ }^{\mathrm{a}}$ No suitable docking poses were found.

where Delta $G$ is the calculated binding energy; $U \mathrm{xxx} \_b$ is the van der Waals, Coulombic, and Cavity energy terms from the bound state; $U x_{x x} f$ is the van der Waals, Coulombic, and Cavity energy terms from the free state.

LIE method applied to our ligands provided a statistically significant correlation between calculated and experimental data, underpinning the validity of predicted docking poses (Table 5).
TABLE 6: Statistical parameters for LIE R-model and S-model.

\begin{tabular}{lccccc}
\hline Model & $R^{2}$ & SD & $F$ & $P$ & $R_{\mathrm{cv}}^{2}$ \\
\hline R-model & 0.813 & 0.218 & 13.1 & 0.00125 & 0.64 \\
S-model & 0.751 & 0.242 & 10.0 & 0.00232 & 0.511 \\
\hline
\end{tabular}

It is worth noting that chiral compounds under study were synthesized and tested as racemic mixture. Consequently, all calculations were carried out for all enantiomers, and quantitative models were generated for both $\mathrm{R}$ (Rmodel) and $\mathrm{S}$ forms (S-model) separately. Obtained $\Delta G$ values indicate that the R-model works slightly better than the $\mathrm{S}$-model in predicting activity, as demonstrated by statistical correlation values (Table 6); however, the S-model is able to predict the binding energy with acceptable approximation indicating that experimental activity can be due to the contribution of both enantiomers.

This result is confirmed from the analysis of fragments docking poses in fact that no relevant differences can be observed in the binding of enantiomeric forms of chiral compounds, in the MMP-2 active site.

Moreover, differently than expected, just ligand la is able to chelate the zinc ion, providing an explanation of the higher activity observed for this compound. Other fragments give a monodentate binding of the catalytic zinc, and the other electron donating group is usually involved in $\mathrm{H}$-bond interactions with surrounding residues, such as the Pro221 carbonyl oxygen (e.g., 1d), except for compounds containing the imidazole ring (e.g., le), involved in a $\pi-\pi$ stacking with the His201 side chain, which represents one of the main interactions formed by MMPIs in the $S_{1}^{\prime}$ pocket (Figure 3). This behavior can be attributed to the strict geometrical requirements, which must be fulfilled by chelating group around the zinc ion in MMPs active site.

The binding of sulfonamide derivatives 25a, 25d, and 25e was studied as well through docking calculation and subsequent refinement as previously described on MMP-1, -8 , and -9 (Table 7 ). No statistical correlations are provided in these cases because of the few available data. Docking results show all ligands occupying the $S_{1}^{\prime}$ site, except for MMP-1. This isoform, in fact, is known for having a short $S_{1}^{\prime}$ pocket, unable to accommodate the large biphenylether portion of 
TABLE 7: Predicted and calculated binding energy (kcal) for sulfonamide ligands toward MMP-1, -8 , and -9 .

\begin{tabular}{|c|c|c|c|c|c|c|}
\hline \multirow{2}{*}{ Compound } & \multicolumn{2}{|c|}{ MMP-1 } & \multicolumn{2}{|c|}{ MMP-8 } & \multicolumn{2}{|c|}{ MMP-9 } \\
\hline & $\Delta G \exp$ & $\Delta G$ calc & $\Delta G \exp$ & $\Delta G$ calc & $\Delta G \exp$ & $\Delta G$ calc \\
\hline $25 a$ & -4.074 & -4.098 & -5.460 & -5.532 & -5.178 & -5.168 \\
\hline $25 d R$ & -422 & -4.247 & -6870 & -6.504 & $-67+2$ & -6.840 \\
\hline $25 d S$ & $-4.22^{2}$ & -4.176 & $-0.8 / 0$ & -6.870 & -0.705 & -6.528 \\
\hline $25 \mathrm{e} R$ & -4524 & -4.527 & -4740 & -4.365 & -5042 & -4.970 \\
\hline $25 \mathrm{e} S$ & 4.024 & -4.522 & & -5.408 & & -5.165 \\
\hline
\end{tabular}

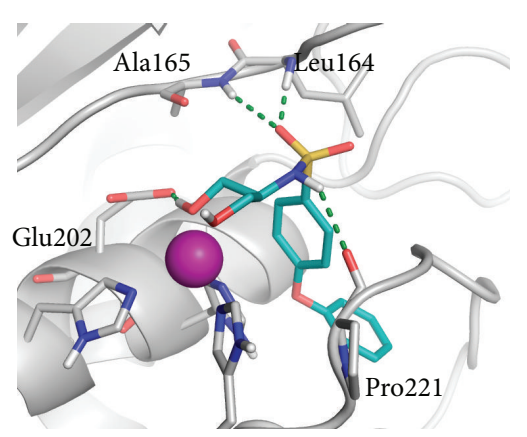

(a)

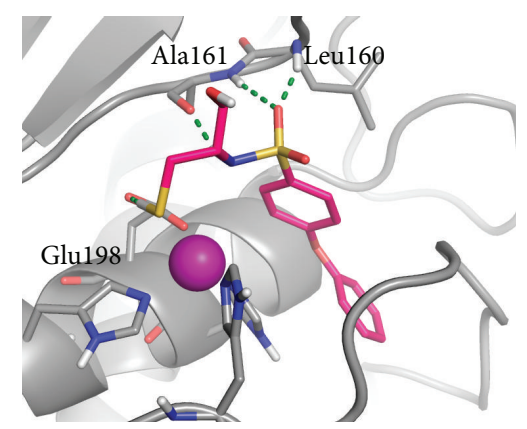

(b)

FIGURE 4: Docked poses of 25a into the MMP-2 active site (a) and 25d into MMP- 8 active site (b). MMP-2 and MMP- 8 are represented, respectively, as a grey and dark grey cartoons. Ligands and most relevant residues are depicted as sticks. H-bonds are represented as green dashed lines.

these ligands. The imidazole ring of compounds $25 \mathbf{e}$, the more active towards MMP-1, occupy the hydrophobic pocket of this protein.

Binding mode of sulfonamide derivatives to the other MMPs is well conserved, regardless of chirality: MMP-2, -8 , and -9 have a deep $S_{1}^{\prime}$ site able to locate the hydrophobic biphenyl ether, whose proximal aromatic ring interacts with the imidazole ring of His201, and the distal ring provides hydrophobic interactions in binding pocket. The sulfonamide moiety provides two $\mathrm{H}$-bonds between a sulfone oxygen and Ala165 and Leu164 NH (MMP-2 numbering) and the sulfonamide $\mathrm{NH}$ and the Pro221 CO or alternatively Ala165 $\mathrm{CO}$ (Figure 4). Main differences are observed for the binding of the ZBG; in MMP-2, the ZBG of $\mathbf{2 5 a}$ maintains the ability to chelate the zinc ion.

This chelation, not observed in MMP-8 and -9, can explain the higher activity observed for this ligand in MMP-2.

MMP-8 and -9 zinc ions coordinate all ligands in a monodentate fashion with a similar geometry, similarly to what observed for the ZBG in MMP-2. Therefore, as no chelation is provided by the ZBG in MMP-8 and MMP-9, the zinc thiophilicity seems to play a relevant role in determining activity toward these isoforms.

\section{Conclusion}

Herein, we described the design, synthesis, inhibitory activity, and molecular modeling studies of new non-hydroxamatebased MMPIs. The adopted synthetic strategy enabled the setting-up of a small ZBGs library through a simple and easily accessible pool of reactions. The biological screening of this library led to the identification of two ZBGs that were incorporated in a more complex structure able to interact with the $S_{1}^{\prime}$ enzymatic site. The biological data for compounds 25a and 25e confirmed the inhibition trend of the respective ZBGs against MMP-2. Compound 25d, containing a less potent chelating group (1d versus $\mathbf{1 a}$ and $\mathbf{1 e}$ ), was equipotent to 25a against MMP-2 and more potent than 25a against MMP-8 and MMP-9 (10- and 13-fold, resp.). Molecular modeling studies provided a rationalization of the experimental data, suggesting a putative binding mode of studied ligands in MMPs active site. These preliminary results indicate the importance of testing and selecting firstly compounds containing the minimums structural requirements necessary for a specific biological activity. Furthermore, taking in consideration the complex role of MMPs in the cellular and tumoral homeostasis, the development of selective inhibitors is desirable in order to shed further light on the protein function, signalling pathways, and role in disease of different MMPs [32-34]. Thus, compound 25d identified in this preliminary study as MMP-8 and MMP-9 inhibitors could be submitted to a rational process of hit optimization with the aim to improve its potency and selectivity of action. The introduction of these new fragments into different peptide structures with the aim to synthesize selective MMPs inhibitors and to explore their structure-activity relationships is currently under study in our laboratory.

\section{Experimental}

6.1. MMP Inhibition Assays. Pro-MMP-1, pro-MMP-2, proMMP-8, and pro-MMP-9 were purchased from Calbiochem. 
Proenzymes were activated immediately prior to use with $p$ aminophenylmercuric acetate (APMA $2 \mathrm{mM}$ for $1 \mathrm{~h}$ at $37^{\circ} \mathrm{C}$ for MMP-2 and MMP-8, APMA $2 \mathrm{mM}$ for $2 \mathrm{~h}$ at $37^{\circ} \mathrm{C}$ for MMP-1, and APMA $1 \mathrm{mM}$ for $1 \mathrm{~h}$ at $37^{\circ} \mathrm{C}$ for MMP-9). For assay measurements, the inhibitor stock solutions $(10 \mathrm{mM}$ in DMSO) were further diluted, at seven different concentrations $(0.01 \mathrm{nM}-200 \mu \mathrm{M})$ for each MMP in the fluorometric assay buffer (FAB: Tris $50 \mathrm{mM}, \mathrm{pH}=7.5, \mathrm{NaCl} 150 \mathrm{mM}$, $\mathrm{CaCl}_{2} 10 \mathrm{mM}$, Brij $350.05 \%$, and DMSO 1\%). Activated enzyme (final concentration $0.56 \mathrm{nM}$ for MMP-2, $1.3 \mathrm{nM}$ for MMP-9, $1.5 \mathrm{nM}$ for MMP-8, and 2.0 nM for MMP-1) and inhibitor solutions were incubated in the assay buffer for $4 \mathrm{~h}$ at $25^{\circ} \mathrm{C}$. After the addition of $20 \mu \mathrm{M}$ solution of the fluorogenic substrate Mca-Lys-Pro-Leu-Gly-Leu-Dap(Dnp)Ala-Arg- $\mathrm{NH}_{2}$ (Bachem) for all the enzymes in DMSO (final concentration $2 \mu \mathrm{M}$ ), the hydrolysis was monitored every $15 \mathrm{~s}$ for $15 \mathrm{~min}$ recording the increase in fluorescence $(\lambda \mathrm{ex}=$ $325 \mathrm{~nm}$; $\lambda$ em $=395 \mathrm{~nm}$ ) using a Molecular Devices SpectraMax Gemini XS plate reader. The assays were performed in triplicate in a total volume of $200 \mu \mathrm{L}$ per well in 96well microtiter plates (Corning, black, NBS). The MMP inhibition activity was expressed in relative fluorescent units (RFUs). Percent of inhibition was calculated from control reactions without the inhibitor. $\mathrm{IC}_{50}$ was determined using the formula: $V_{i} / V_{o}=1 /\left(1+[\mathrm{I}] / \mathrm{IC}_{50}\right)$, where $V_{i}$ is the initial velocity of substrate cleavage in the presence of the inhibitor at concentration [I], and $V_{o}$ is the initial velocity in the absence of the inhibitor. Results were analyzed using SoftMax Pro software and Origin software.

6.2. General. Reagents, starting materials, and solvents were purchased from commercial suppliers and used as received. Analytical TLC was performed on plates coated with a $0.25 \mathrm{~mm}$ layer of silica gel 60 F254 Merck and preparative TLC on $20 \mathrm{~cm} \times 20 \mathrm{~cm}$ glass plates coated with a $0.5 \mathrm{~mm}$ layer of silica gel PF254Merck. Silica gel 60 (300-400 mesh, Merck) was used for flash chromatography. Melting points were determined by a Kofler apparatus and are uncorrected. ${ }^{1} \mathrm{H}$ NMR and ${ }^{13} \mathrm{C}$ NMR spectra were recorded with a Varian-400 spectrometer, operating at 400 and $100 \mathrm{MHz}$, respectively. Chemical shifts are reported in $\delta$ values (ppm) relative to internal $\mathrm{Me}_{4} \mathrm{Si}$, and $J$ values are reported in hertz $(\mathrm{Hz})$. ESIMS experiments were performed on an Applied Biosystems API 2000 triple-quadrupole spectrometer.

6.2.1. 2-(tert-Butyloxycarbonyl)-1,3-dihydroxypropane (2). To a $25 \mathrm{~mL}$ round-bottom flask, 2-aminopropane-1,3-diol 1a (11 mmol) (Sigma-Aldrich, 98\%) was added and dissolved in a 1:1 mixture water/1,4-dioxan $(10 \mathrm{~mL})$. After few minutes, di-tert-butyl dicarbonate (1.2 eq) and $\mathrm{KOH}$ until $\mathrm{pH} 8$ were added. The reaction was stirred for $48 \mathrm{~h}$, washed with $\mathrm{H}_{3} \mathrm{O}^{+}$, dried with $\mathrm{Na}_{2} \mathrm{SO}_{4}$, and evaporated under reduced pressure (yield: 98\%); ${ }^{1} \mathrm{H}-\mathrm{NMR}$ (400 $\mathrm{MHz}, \mathrm{CDCl}_{3}$ ) $\delta 1.34$ (s, 9H, Boc); $\delta$ 3.59-3.63 (m, 1H, H-2); $\delta 3.72-3.87$ ( $\mathrm{m}, 4 \mathrm{H}, \mathrm{H}-1$ and $\mathrm{H}-3)$; $\delta 5.15$ (bs, $1 \mathrm{H}, \mathrm{NHBoc})$ ).

6.2.2. 2-(tert-Butoxycarbonylamino)propane-1,3-diyl bis(4Methylbenzenesulfonate) (3). To a $25 \mathrm{~mL}$ round-bottom flask, 2 (10 mmol) was added and dissolved in dry DCM $(10 \mathrm{~mL})$. After reached $0^{\circ} \mathrm{C}$, paratoluensulfonyl chloride $(2.4$ eq) and TEA (3 eq) were added. The reaction was stirred for $10 \mathrm{~h}$, washed with water, dried with $\mathrm{Na}_{2} \mathrm{SO}_{4}$, and evaporated under reduced pressure. The crude was then purified by chromatographic column using $n$-hexane/AcOEt 2:1 as eluent (yield: $85 \%) ;{ }^{1} \mathrm{H}-\mathrm{NMR}\left(400 \mathrm{MHz}, \mathrm{CDCl}_{3}\right) \delta 1.34(\mathrm{~s}$, 9H, Boc); 4.00-4.06(m, 5H, H-1, H-2, and H-3); 4.89 (bs, NHBoc); 7.31 (d, $J=8 \mathrm{~Hz}, 4 \mathrm{H}$, aryl); 7.71 (d, 4H, aryl).

\section{General Procedure for the Synthesis of Symmetric Ligands 3-Aminopentanedinitrile (1b) and 1,3-Diazidopropan-2-amine (1c)}

To a $25 \mathrm{~mL}$ round-bottom flask, 3 (5 mmol) was added and dissolved in DMF (10 mL). TEA (3 eq) and TEACN (2.4 eq) or $\mathrm{NaN}_{3}$ (2.4 eq) were then added, and the reaction was stirred for $10 \mathrm{~h}$ at room temperature. The reaction mixtures were washed with water, dried with $\mathrm{Na}_{2} \mathrm{SO}_{4}$, and evaporated under reduced pressure. The crudes $\mathbf{4}$ and $\mathbf{5}$ were purified by chromatographic column using $n$-hexane/AcOEt: $3 / 1$ as eluent. Data for tert-butyl 1,3-dicyanopropan-2-ylcarbamate (4), Data for tert-butyl 1,3-dicyanopropan-2-ylcarbamate (4) $1 \mathrm{H}$ NMR(400 MHz, CDCl3): $\delta 1.41$ (s, 9H); 2.73-2.82 (m, 4H,H-2 and H-4); 3.47-3.50 (m, 1H, H-3); 5.06 (bs, 1H, NHBoc). Data for tert-butyl 1,3-diazidopropan-2-ylcarbamate (5) 1H-NMR (400 MHz, CDCl3): $\delta 1.49$ (s, 9H, Boc); 3.40-3.52 (m, 4H, H1 and $\mathrm{H}-3$ ); 3.86-3.90 (m,1H, H-2); 4.77 (bs, $1 \mathrm{H}, \mathrm{NHBoc).} \mathrm{A}$ solution of derivatives 4 or $5(1 \mathrm{mmol})$ in $\mathrm{CH}_{2} \mathrm{Cl}_{2}(10 \mathrm{~mL})$ was treated with trifluoroacetic acid $(10 \mathrm{~mL})$ and stirred at room temperature. The reaction was stirred for $2 \mathrm{~h}$ at room temperature and evaporated under reduced pressure to yield the corresponding final products as TFA salt.

7.1. 3-Aminopentanedinitrile Trifluoroacetate (1b). Yield: 36\%. ${ }^{1} \mathrm{H}-\mathrm{NMR}\left(400 \mathrm{MHz}, \mathrm{CD}_{3} \mathrm{OD}\right) \delta 3.00-3.03(\mathrm{~m}, 4 \mathrm{H}$, $\mathrm{H}-2$ and $\mathrm{H}-4) ; 3.07(\mathrm{t}, 1 \mathrm{H}, J=6.0 \mathrm{~Hz}) .{ }^{13} \mathrm{C}-\mathrm{NMR}(100 \mathrm{MHz}$, $\left.\mathrm{CD}_{3} \mathrm{OD}\right) \delta 20.7$ (C-3, C-4), 39.5 (C-3), 114.9 (CN). ESI-MS calc for $\mathrm{C}_{15} \mathrm{H}_{17} \mathrm{NO}_{5} \mathrm{~S} 323.08$, found 323.16.

7.2. 1,3-Diazidopropan-2-amine Trifluoroacetate (1c). Yield: $33 \% .{ }^{1} \mathrm{H}-\mathrm{NMR}\left(400 \mathrm{MHz}, \mathrm{CD}_{3} \mathrm{OD}\right) \delta 3.46-3.48(\mathrm{~m}, 1 \mathrm{H}$, $\mathrm{H}-2)$; 3.63-3.77 (m, 4H, H-1, H-3). ${ }^{13} \mathrm{C}-\mathrm{NMR}(100 \mathrm{MHz}$, $\left.\mathrm{CD}_{3} \mathrm{OD}\right) \delta 52.0$ (C-2), 59.0 (C-1 and C-3). ESI-MS calc for $\mathrm{C}_{15} \mathrm{H}_{17} \mathrm{NO}_{5} \mathrm{~S} 323.08$, found 323.16.

\section{General Procedure for Synthesis of Amino Alcohols Derived from Amino Acids (9-11)}

Ethyl chloroformate (1.2 eq) and N-methylmorfoline (1.2 eq) at $0^{\circ} \mathrm{C}$ were added to a solution of Boc-Cys(Trt)-OH (6) or Boc-Ser(OtBu)-OH (7) or flask Boc-His(Boc)-OH (8) $(1 \mathrm{mmol})$ in THF $(4 \mathrm{~mL})$. After $1 \mathrm{~h}$, the reaction was filtered off, and $\mathrm{NaBH}_{4}$ (3 eq) dissolved in $2 \mathrm{~mL}$ of water was added. The reaction was then stirred at room temperature for $3 \mathrm{~h}$, washed with $\mathrm{H}_{3} \mathrm{O}^{+}$, dried with $\mathrm{Na}_{2} \mathrm{SO}_{4}$, and evaporated 
under reduced pressure. Chromatography purification of the corresponding residues using $n$-hexane/AcOEt: $2 / 1$ yielded, in each case, the amino alcohol derivatives.

8.1. tert-Butyl 1-Hydroxy-3-(tritylthio)propan-2-ylcarbamate (9). Yield: 73\%. ${ }^{1} \mathrm{H}-\mathrm{NMR}\left(400 \mathrm{MHz}, \mathrm{CDCl}_{3}\right) \delta 1.38(\mathrm{~s}, 9 \mathrm{H}$, Boc); $2.40-2.42$ (m, 2H, H-3); 3.46-3.51 (m, 3H, H-1, H-2); 4.77 (bs, 1H, NHBoc); 7.20-7.44 (m, 15H, aryl).

8.2. tert-Butyl 1-(tert-Butoxy)-3-hydroxypropan-2-ylcarbamate (10). Yield: 69\%. ${ }^{1} \mathrm{H}-\mathrm{NMR}\left(400 \mathrm{MHz}, \mathrm{CDCl}_{3}\right) \delta 1.08(\mathrm{~s}$, $9 \mathrm{H}) ; 1.41$ (s, 9H); 3.12 (m, 1H, H-3); 3.41-3.49 (m, 2H, H-1, H-3); 3.62 (m, 2H, H-1, H-2); 5.12 (s, NHBoc).

8.3. tert-Butyl 1-Hydroxy-3-(1H-imidazol-4-yl)propan-2-ylcarbamate (11). Yield: $80 \%$. ${ }^{1} \mathrm{H}-\mathrm{NMR}\left(400 \mathrm{MHz}, \mathrm{CDCl}_{3}\right) \delta$ 1.39 (s, 9H); 1.45 (s, 9H); 2.61-2.72 (m, 2H, H-1); 3.12-3.21 (m, 2H, H-3); 3.62 (m, 1H, H-2); 4.98 (bs, NHBoc); 7.00 (s, 1H, imidazole); 8.21(s, $1 \mathrm{H}$, imidazole).

\section{General Procedure for Removal of the Boc Protecting Group: Synthesis of Final Ligands $1 \mathrm{~d}$ and $1 \mathrm{e}$}

The compounds 9 or $\mathbf{1 1}$ were dissolved in a 1:1 mixture DCM/TFA $(10 \mathrm{~mL})$, adding triethylsilane $(0.1 \mathrm{eq})$ as scavenger. The reaction was stirred for $2 \mathrm{~h}$ at room temperature and evaporated under reduced pressure to yield the title derivatives as TFA salt.

9.1. 2-Amino-3-mercaptopropan-1-ol Trifluoroacetate (1d). Amorphous solid (46\%). ${ }^{1} \mathrm{H}-\mathrm{NMR}\left(400 \mathrm{MHz}, \mathrm{D}_{2} \mathrm{O}\right) \delta 2.45-$ 2.49 (m, 2H, H-3); 3.15-3.19 (m, 1H, H-2); 3.67-3.71 (m, 2H, $\mathrm{H}-1) .{ }^{13} \mathrm{C}$ NMR (100 MHz, D $\left.2 \mathrm{O}\right) \delta 30.2$ (C-3) 57.2 (C-2), 63.1 (C-1). ESI-MS calc for $\mathrm{C}_{5} \mathrm{H}_{10} \mathrm{~F}_{3} \mathrm{NO}_{3} \mathrm{~S} 221.20$, found 221.29.

9.2. 2-Amino-3-(1H-imidazol-4-yl)propan-1-ol Ditrifluoroacetate (1e). White solid (39\%), m.p. $218-220^{\circ} \mathrm{C} .{ }^{1} \mathrm{H}$ NMR (400 MHz, CD 3 OD) $\delta 2.90-2.93(\mathrm{~m}, 2 \mathrm{H}, \mathrm{H}-3) ; 3.08-3.12(\mathrm{~m}$, $1 \mathrm{H}, \mathrm{H}-1)$; 3.66-3.71 (m, 2H, H-1); 7.01 (s, 1H, imidazole); 7.89 (s, 1H, imidazole). ${ }^{13} \mathrm{H}-\mathrm{NMR}\left(100 \mathrm{MHz}, \mathrm{CD}_{3} \mathrm{OD}\right) \delta 29.4$ (C3), 58.2 (C-2), 64.1 (C-1) 118.2, 130.1, 134.7 (imidazole). ESIMS calc for $\mathrm{C}_{10} \mathrm{H}_{13} \mathrm{~F}_{6} \mathrm{~N}_{3} \mathrm{O}_{5} 369.22$, found 369.16.

\section{General Procedure for Synthesis of Tosilated Derivatives 12-14}

To a $25 \mathrm{~mL}$ round-bottom flask, 9, 10, or $\mathbf{1 1}(1.1 \mathrm{mmol})$ was added and dissolved in dry DCM $(10 \mathrm{~mL})$. After reached $0^{\circ} \mathrm{C}$, paratoluensulfonyl chloride (1.2 eq) and TEA (1.5 eq) were added. The reaction is stirred for $10 \mathrm{~h}$, washed with water, dried with $\mathrm{Na}_{2} \mathrm{SO}_{4}$, and evaporated under reduced pressure. The crudes were then purified by chromatographic column using $n$-hexane/AcOEt: $3 / 1$ as elution system.

10.1. 2-(tert-Butoxycarbonylamino)-3-(tritylthio)propyl 4-Methylbenzenesulfonate (12). Yield: $73 \% .{ }^{1} \mathrm{H}-\mathrm{NMR}(400 \mathrm{MHz}$, $\left.\mathrm{CDCl}_{3}\right) \delta 1.43(\mathrm{~s}, 9 \mathrm{H}) ; 2.30\left(\mathrm{~s}, 3 \mathrm{H}, \mathrm{CH}_{3}\right) ; 2.33-2.42(\mathrm{~m}, 2 \mathrm{H}, \mathrm{H}-$ 3); 3.55-3.58 (m, 1H, H-1); 3.89-3.93 (m, 3H, H-1, H-2), 4.48 (bs, NHBoc); 7.21-7.37 (m, $17 \mathrm{H}$, aryl); $7.72(\mathrm{~d}, J=8.0 \mathrm{~Hz}, 2 \mathrm{H}$, aryl).

10.2. 3-tert-Butoxy-2-(tert-butoxycarbonylamino)propyl 4-Methylbenzenesulfonate (13). Yield: $77 \% .{ }^{1} \mathrm{H}-\mathrm{NMR}$ $\left(400 \mathrm{MHz} \mathrm{CDCl}_{3}\right) \delta 1.08(\mathrm{~s}, 9 \mathrm{H}) ; \delta 1.43$ (s, 9H); 2.31 (s, 3H, $\mathrm{CH}_{3}$ ); 3.14-3.23 (m, 2H, H-1, H-3); 3.87-3.91 (m, 2H, H-1, H-3); 4.02-4.08 (m, 1H, H-2); 4.92 (bs, NHBoc); 7.16 (d, $J=8.1 \mathrm{~Hz}, 2 \mathrm{H}$, aryl); 7.89 (d, 2H, aryl).

10.3. tert-Butyl 4-(2-(tert-Butoxycarbonylamino)-3-(tosyloxy) propyl)-1H-imidazole-1-carboxylate (14). Yield: $73 \% .{ }^{1} \mathrm{H}$ $\mathrm{NMR}\left(400 \mathrm{MHz}, \mathrm{CDCl}_{3}\right) \delta 1.38(\mathrm{~s}, 9 \mathrm{H}) ; 1.41$ (s, 9H); 2.31 (s, $3 \mathrm{H}, \mathrm{CH}_{3}$ ); 2.59-2.65 (m, 2H, H-1); 3.53-3.56 (m, 1H, H-3); 3.74-3.82 (m, 1H, H-3); 4.00-4.07 (m, 1H, H-2); $\delta 5.01$ (bs, NHBoc); 7.01 (s, $1 \mathrm{H}$, imidazole); 7.19 (d, $J=8.0 \mathrm{~Hz}, 2 \mathrm{H}$, aryl); 7.80 (d, 2H, aryl); 7.89 (s, 1H, imidazole).

\section{General Procedure for the Synthesis of Thio Derivatives 15 and 16}

To a $25 \mathrm{~mL}$ round-bottom flask, 12 or $14(1.1 \mathrm{mmol})$ was added, and dissolved in DMF (10 mL). TEA (1.5 eq) and Trt$\mathrm{SH}$ (1.2 eq) were then added and the reaction was stirred for $10 \mathrm{~h}$ at room temperature. The reaction mixture was then washed with water, dried with $\mathrm{Na}_{2} \mathrm{SO}_{4}$, and evaporated under reduced pressure. The crudes were then purified by chromatographic column using TLC: $n$-hexane/AcOEt: $4 / 1$ as eluent system.

11.1. tert-Butyl 1,3-bis(Tritylthio)propan-2-ylcarbamate (15). Yield: $81 \%$. ${ }^{1} \mathrm{H}-\mathrm{NMR}\left(400 \mathrm{MHz}, \mathrm{CDCl}_{3}\right) \delta 1.39$ (s, 9H); $2.38-$ 2.41 (m, 4H, H-1, H-3); 4.01-4.05 (m, 1H, H-2); 4.48 (bs, NHBoc); 7.08-7.23 (m, 30H, aryl).

11.2. tert-Butyl 4-(2-(tert-Butoxycarbonylamino)-3-(tritylthio) propyl)-1H-imidazole-1-carboxylate (16). Yield: $79 \% .{ }^{1} \mathrm{H}-$ NMR $\left(400 \mathrm{MHz}, \mathrm{CDCl}_{3}\right) \delta 1.42(\mathrm{~s}, 9 \mathrm{H}) ; 2.51-2.64(\mathrm{~m}$, $4 \mathrm{H}, \mathrm{H}-1, \mathrm{H}-3$ ); 4.20-4.26 (m, 1H, H-2); 4.48 (bs, NHBoc); 7.08-7.23 (m, 16H, aryl); 7.91 (s, 1H, imidazole).

\section{Synthesis of Final Ligands If and $1 \mathrm{~g}$}

The compounds $\mathbf{1 5}$ or $\mathbf{1 6}$ were dissolved in a $1: 1$ mixture DCM/TFA $(10 \mathrm{~mL})$, adding triethylsilane (0.1 eq) as scavenger. The reaction was stirred for $2 \mathrm{~h}$ at room temperature and evaporated under reduced pressure to yield the title derivatives as TFA salt.

12.1. 2-Aminopropane-1,3-dithiol Trifluoroacetate (1f). Amorphous solid (59\%). ${ }^{1} \mathrm{H}$ NMR $\left(400 \mathrm{MHz}, \mathrm{D}_{2} \mathrm{O}\right) \delta 2.64$ (dd, $2 \mathrm{H}, J=6.8$ and $11.2 \mathrm{~Hz}, \mathrm{H}-1, \mathrm{H}-3) ; 2.74$ (dd, $J=5.2$ and $6.9 \mathrm{~Hz}, 2 \mathrm{H}, \mathrm{H}-1, \mathrm{H}-3) .{ }^{13} \mathrm{C} \mathrm{NMR}\left(100 \mathrm{MHz}, \mathrm{D}_{2} \mathrm{O}\right) \delta 30.1(\mathrm{C}-$ 1, C-3), 55.0 (C-2). ESI-MS calc for $\mathrm{C}_{5} \mathrm{H}_{10} \mathrm{~F}_{3} \mathrm{NO}_{2} \mathrm{~S}_{2}$ : 237.01; found 237.11 .

12.2. 2-Amino-3-(1H-imidazol-2-yl)propane-1-thiol Ditrifluoroacetate (1g). White solid (61\%), m.p. $196-198^{\circ}$ C. ${ }^{1} \mathrm{H}$ NMR $\left(400 \mathrm{MHz}, \mathrm{CD}_{3} \mathrm{OD}\right) \delta 2.79(\mathrm{dd}, 1 \mathrm{H}, J=5.7$ and $10.1 \mathrm{~Hz}, \mathrm{H}-1)$; 
2.90 (dd, $1 \mathrm{H}, \mathrm{H}-1)$; $3.18-3.25$ (m, 2H, H-3); 3.61-3.70 (m, $1 \mathrm{H}$. $\mathrm{H}-2) .{ }^{13} \mathrm{H}-\mathrm{NMR}\left(100 \mathrm{MHz}, \mathrm{CD}_{3} \mathrm{OD}\right) \delta 25.8(\mathrm{C}-1) ; 26.4(\mathrm{C}-3)$, 52.3 (C-2), 118.2 (imidazole), 134.7 (imidazole). ESI-MS calc for $\mathrm{C}_{8} \mathrm{H}_{12} \mathrm{~F}_{3} \mathrm{~N}_{3} \mathrm{O}_{2} \mathrm{~S}$ : 271.06; found 271.10.

\section{General Procedure for the Synthesis of Cyano Derivatives 17 and 18}

To a $25 \mathrm{~mL}$ round-bottom flask, $\mathbf{1 2}$ or $\mathbf{1 3}(1.1 \mathrm{mmol})$ was added and dissolved in DMF $(10 \mathrm{~mL})$. TEA (1.5 eq) and TEACN (1.2 eq) were added, and the reaction was stirred for $10 \mathrm{~h}$ at room temperature. The reaction mixtures were then washed with water, dried with $\mathrm{Na}_{2} \mathrm{SO}_{4}$, and evaporated under reduced pressure. The crudes were purified by chromatographic column using $n$-hexane/AcOEt: $3 / 1$

13.1. tert-Butyl 1-Cyano-3-(tritylthio)propan-2-ylcarbamate (17). Yield: $84 \% .{ }^{1} \mathrm{H}-\mathrm{NMR}\left(400 \mathrm{MHz}, \mathrm{CDCl}_{3}\right) \delta 1.42$ (s, $9 \mathrm{H}$ ); $2.29-2.33$ (m, 2H, H-3); 2.71-2.86 $8 \mathrm{~m}, 2 \mathrm{H}, \mathrm{H}-1)$; 3.86-3.91 (m, 1H, C-2); 4.97 (bs, NHBoc); $\delta$ 7.08-7.45 (m, $15 \mathrm{H}$, aryl).

13.2. tert-Butyl 1-tert-Butoxy-3-cyanopropan-2-ylcarbamate (18). Yield: $81 \% .{ }^{1} \mathrm{H}-\mathrm{NMR}\left(400 \mathrm{MHz}, \mathrm{CDCl}_{3}\right) \delta 1.12$ (s, 9H); 1.41 (s, 9H); 2.69 (m, 2H, H-3); 3.23-3.41 (m, 2H, H-1); 3.903.94 (m, 1H, H-2); 4.99 (bs, NHBoc).

\section{Synthesis of Final Ligands $1 \mathrm{~h}$ and $1 \mathrm{i}$}

The intermediates $\mathbf{1 7}$ and $\mathbf{1 8}$ were dissolved in a 1:1 mixture DCM/TFA $(10 \mathrm{~mL})$, adding triethylsilane $(0.1 \mathrm{eq})$ as scavenger. The reaction was stirred for $2 \mathrm{~h}$ at room temperature and evaporated under reduced pressure to afford the title compounds as TFA salt.

14.1. 3-Amino-4-mercaptobutanenitrile Trifluoroacetate (1h). Amorphous solid (65\%). ${ }^{1} \mathrm{H}$ NMR $\left(400 \mathrm{MHz}, \mathrm{CD}_{3} \mathrm{OD}\right) \delta$ 3.09-3.20 (m, 4H, H-2, H-4); 3.87-3.90 (m, 1H, H-3). ${ }^{13} \mathrm{C}$ NMR $\left(100 \mathrm{MHz}, \mathrm{CD}_{3} \mathrm{OD}\right) \delta 20.3$ (C-2), 38.3 (C-4), 46.1 (C3), 115.4 (C-1). ESI-MS calc for $\mathrm{C}_{6} \mathrm{H}_{9} \mathrm{~F}_{3} \mathrm{~N}_{2} \mathrm{O}_{2} \mathrm{~S} 230.01$, found 230.12 .

14.2. 3-Amino-4-hydroxybutanenitrile Trifluoroacetate (1i). White solid (63\%), m.p. $131-133^{\circ} \mathrm{C} .{ }^{1} \mathrm{H}-\mathrm{NMR}(400 \mathrm{MHz}$, $\left.\mathrm{CD}_{3} \mathrm{OD}\right) \delta$ 2.41-2.53 (m, 2H, H-2); 3.76-3.89 (m, 3H, H-3, $\mathrm{H}-4) .{ }^{13} \mathrm{C}$ NMR $\left(100 \mathrm{MHz}, \mathrm{CD}_{3} \mathrm{OD}\right) \delta 21.1(\mathrm{C}-2), 50.0$ (C-3), 61.3 (C-4), 114.7 (C-1) ESI-MS calc for $\mathrm{C}_{6} \mathrm{H}_{9} \mathrm{~F}_{3} \mathrm{~N}_{2} \mathrm{O}_{3}$ 214.06, found 214.16.

\section{General Procedure for the Synthesis of Azido Derivatives 19-21}

To a $25 \mathrm{~mL}$ round-bottom flask, 12, 13, or $\mathbf{1 4}(1.1 \mathrm{mmol})$ were added and dissolved in DMF $(10 \mathrm{~mL})$. TEA (3 eq) and $\mathrm{NaN}_{3}$ (2.4 eq) were added, and the reactions were stirred for $10 \mathrm{~h}$ at room temperature. The reaction mixtures were washed with water, dried with $\mathrm{Na}_{2} \mathrm{SO}_{4}$, and evaporated under reduced pressure. The crudes were then purified by chromatographic column using $n$-hexane/AcOEt: $3 / 1$ as eluent system.

15.1. tert-Butyl 1-Azido-3-(tritylthio)propan-2-ylcarbamate (19). Yield: $75 \% .{ }^{1} \mathrm{H}-\mathrm{NMR}\left(400 \mathrm{MHz}, \mathrm{CDCl}_{3}\right) \delta 1.49$ (s, 9H); 2.54-2.62 (m, 2H, H-3); 3.29-3.35 (m, 2H, H-1); 3.88-3.90 (m, 1H, H-2); 4.82 (bs, NHBoc).

15.2. tert-Butyl 1-Azido-3-tert-butoxypropan-2-ylcarbamate (20). Yield: $72 \% .{ }^{1} \mathrm{H}-\mathrm{NMR}\left(400 \mathrm{MHz}, \mathrm{CDCl}_{3}\right) \delta 1.18$ (s, 9H); 1.43 (s, 9H); 3.01-3.23 (m, 2H, H-1); 3.81-3.90 (m, 3H, H-2, H-3); 4.91 (bs, NHBoc).

15.3. tert-Butyl 4-\{3-Azido-2-[(tert-butoxycarbonyl)amino] propyl\}-1H-imidazole-1-carboxylate (21). Yield: $70 \% .{ }^{1} \mathrm{H}$ NMR $\left(400 \mathrm{MHz}, \mathrm{CDCl}_{3}\right) \delta 1.39(\mathrm{~s}, 9 \mathrm{H}) ; 1.59(\mathrm{~s}, 9 \mathrm{H}) ; 3.21-3.33$ (m, 4H, H-1, H-3); 3.98-4.03 (m, 1H, C-2); 4.50 (bs, NHBoc).

\section{Synthesis of Final Derivatives $1 \mathbf{j}-11$}

The intermediates 19, 20, and 21 were dissolved in a 1:1 mixture DCM/TFA $(10 \mathrm{~mL})$, adding triethylsilane $(0.1 \mathrm{eq})$ as scavenger. The reaction was stirred for $2 \mathrm{~h}$ at room temperature and evaporated under reduced pressure to afford the title compounds as TFA salt.

16.1. 2-Amino-3-azidopropane-1-thiol Trifluoroacetate (1j). Amorphous solid (38\%). ${ }^{1} \mathrm{H}-\mathrm{NMR}\left(400 \mathrm{MHz}, \mathrm{D}_{2} \mathrm{O}\right) \delta 2.76-$ 2.82 (m, 2H, H-3); 3.58-3.62 (m, 2H, H-2, H-1); 3.78-3.81 (m, $1 \mathrm{H}, \mathrm{H}-1) .{ }^{13} \mathrm{C}$ NMR $\left(100 \mathrm{MHz}, \mathrm{D}_{2} \mathrm{O}\right) \delta 30.6$ (C-1), 51.8 (C2), 58.9 (C-3). ESI-MS calc for $\mathrm{C}_{5} \mathrm{H}_{9} \mathrm{~F}_{3} \mathrm{~N}_{4} \mathrm{O}_{2} \mathrm{~S} 264.04$, found 264.12

16.2. 2-Amino-3-azidopropane-1-ol Trifluoroacetate (1k). Amorphous solid (35\%). ${ }^{1} \mathrm{H}-\mathrm{NMR}\left(400 \mathrm{MHz}, \mathrm{D}_{2} \mathrm{O}\right) \delta$ 3.30-3.33 (m, 1H, H-2); 3.40-3.46 (m, 2H, H-3); 3.53-3.64 $(\mathrm{m}, 2 \mathrm{H}, \mathrm{H}-1) .{ }^{13} \mathrm{C}$ NMR $\left(100 \mathrm{MHz}, \mathrm{D}_{2} \mathrm{O}\right) \delta 50.2(\mathrm{C}-3), 52.0$ (C-2), $59.1(\mathrm{C}-1)$. ESI-MS calc for $\mathrm{C}_{5} \mathrm{H}_{9} \mathrm{~F}_{3} \mathrm{~N}_{4} \mathrm{O}_{3} 230.15$, found 230.27 .

16.3. 1-Azido-3-(1H-imidazol-4-yl)propan-2-amine Ditrifluoroacetate (1l). Amorphous solid (41\%). ${ }^{1} \mathrm{H}-\mathrm{NMR}(400 \mathrm{MHz}$, $\left.\mathrm{CD}_{3} \mathrm{OD}\right) \delta 3.12-3.15(\mathrm{~m}, 2 \mathrm{H}, \mathrm{H}-1) ; 3.62-3.66(\mathrm{~m}, 1 \mathrm{H}$, $\mathrm{H}-2)$; $3.62-3.66(\mathrm{~m}, 1 \mathrm{H}, \mathrm{H}-2)$; $3.70-3.83(\mathrm{~m}, 2 \mathrm{H}, \mathrm{H}-3)$; 7.48 (s, $1 \mathrm{H}$, imidazole); 8.86 (s, $1 \mathrm{H}$, imidazole). ${ }^{13} \mathrm{C}$ NMR $\left(100 \mathrm{MHz}, \mathrm{CD}_{3} \mathrm{OD}\right) \delta 25.3$ (C-3), 49.7 (C-2), 51.2 (C-1), 118.1, 128.1,134.7(C-imidazole). ESI-MS calc for $\mathrm{C}_{10} \mathrm{H}_{12} \mathrm{~F}_{6} \mathrm{~N}_{6} \mathrm{O}_{4}$ 394.23, found 394.31 .

16.4. 4-Phenoxybenzene-1-sulfonyl Chloride (24). In a $25 \mathrm{~mL}$ round-bottom flask, $22(11.75 \mathrm{mmol})$ was dissolved in dry DCM $(10 \mathrm{~mL})$, and chlorosulphonic acid $(11.75 \mathrm{mmol}$.) was added at $0^{\circ} \mathrm{C}$. The reaction was stirred for $2 \mathrm{~h}$, evaporated under vacuum, and used for next step without further purification. The reaction mixture was indeed dissolved in thionyl chloride at $0^{\circ} \mathrm{C}$ and refluxed for $5 \mathrm{~h}$ to yield after evaporation product 24 with $95 \%$ yield. ${ }^{1} \mathrm{H}-\mathrm{NMR}(400 \mathrm{MHz}$, 
$\left.\mathrm{CDCl}_{3}\right) \delta 7.01-7.148 \mathrm{~m}, 5 \mathrm{H}$, aryl); $7.41(\mathrm{~d}, J=8.6 \mathrm{~Hz}, 2 \mathrm{H}$, aryl); $7.82(\mathrm{~d}, 2 \mathrm{H}$, aryl).

16.5. N-(1,3-Dihydroxypropan-2-yl)-4-phenoxybenzenesulfonamide (25a). To a $25 \mathrm{~mL}$ round-bottom flask, $1 \mathrm{a}(3 \mathrm{mmol})$ was added and dissolved in acetone $(10 \mathrm{~mL}) \cdot \mathrm{NaHCO}_{3}$ (1.5 eq.) and 24 (1.2 eq.) were added, and the reaction was stirred for $24 \mathrm{~h}$ at room temperature. The reaction mixture was then washed with water, dried with $\mathrm{Na}_{2} \mathrm{SO}_{4}$, and evaporated under reduced pressure. The crude was purified by chromatographic column using AcOEt/acetone 9/1 as eluent system. Amorphous solid (55\%). ${ }^{1} \mathrm{H}-\mathrm{NMR}(400 \mathrm{MHz}$, $\left.\mathrm{CD}_{3} \mathrm{OD}\right) \delta 3.19-3.21(\mathrm{~m}, 1 \mathrm{H}, \mathrm{H}-2) ; 3.48-3.54(\mathrm{~m}, 4 \mathrm{H}, \mathrm{H}-1$, $\mathrm{H}-3$ ); 7.04-7.09 (m, 5H, aryl); 7.40-7.43 (m, 2H, aryl); 7.84$7.89\left(\mathrm{~m}, 2 \mathrm{H}\right.$, aryl). ${ }^{13} \mathrm{C}$ NMR $\left(100 \mathrm{MHz}, \mathrm{CD}_{3} \mathrm{OD}\right) \delta 56.7$ (C2), 60.9 (C-1, C-3), 117.4, 117.7, 120.0, 121.4, 129.2, 130.1, 132.3, 151.1, 159.2(aryl). ESI-MS calc for $\mathrm{C}_{15} \mathrm{H}_{17} \mathrm{NO}_{5} \mathrm{~S} 323.08$; found 323.16 .

16.6. N-(1-Hydroxy-3-mercaptopropan-2-yl)-4-phenoxybenzenesulfonamide (25d). To a $25 \mathrm{~mL}$ round-bottom flask, 2amino-3-(tritylthio)propan-1-ol (3 mmol) were added and dissolved in DMF (10 mL). $\mathrm{Cs}_{2} \mathrm{CO}_{3}$ (1.5 eq.) and 24 (1.2 eq.) were then added, and the reaction was stirred for $24 \mathrm{~h}$ at room temperature. The reaction mixtures were washed with water, dried with $\mathrm{Na}_{2} \mathrm{SO}_{4}$, and evaporated under reduced pressure. The compound N-(1-hydroxy-3-(tritylthio)propan2-yl)-4-phenoxybenzenesulfonamide was purified by chromatographic column using $n$-hexane/AcOEt: $2 / 1$. Yield: $42 \%$. ${ }^{1} \mathrm{H}-\mathrm{NMR}\left(400 \mathrm{MHz}, \mathrm{CDCl}_{3}\right) \delta 2.34(\mathrm{~d}, J=8.0 \mathrm{~Hz}, 2 \mathrm{H}$, H-3); 3.18-3.23 (m, 1H, H-2); 3.42-3.49 (m, 2H, H-1); 7.14$7.70(\mathrm{~m}, 24 \mathrm{H}$, aryl); $7.74(\mathrm{~d}, 2 \mathrm{H}$, aryl). This intermediate was then dissolved in a 1:1 mixture DCM/TFA $(10 \mathrm{~mL})$, adding triethylsilane $(0.1 \mathrm{eq})$ as scavenger. The reaction was stirred for $2 \mathrm{~h}$ at room temperature and evaporated under reduced pressure to afford the title compound as an amorphous solid. Yield: $92 \% .{ }^{1} \mathrm{H}-\mathrm{NMR}\left(400 \mathrm{MHz}, \mathrm{CDCl}_{3}\right) \delta 2.65-2.70(\mathrm{~m}, 2 \mathrm{H}$, $\mathrm{H}-3$ ); 3.35-3.40 (m, 1H, H-2); 3.64-3.79 (m, 2H, H-1); 7.037.09 (m, 5H, aryl); 7.37 (d, $J=6.8 \mathrm{~Hz}, 2 \mathrm{H}, \operatorname{aryl}) ; 7.84(\mathrm{~d}, 2 \mathrm{H}$, aryl). ${ }^{13} \mathrm{C}$ NMR $\left(100 \mathrm{MHz}, \mathrm{CDCl}_{3}\right) \delta 26.6$ (C-3), 51.1 (C-1), 62.9 (C-3), 118.0, 121.0, 129.6, 130.5, 138.2, 152.0, 160.1(aryl). ESI-MS calc for $\mathrm{C}_{15} \mathrm{H}_{17} \mathrm{NO}_{4} \mathrm{~S}_{2}$ 339.06; found 339.12.

16.7. N-(1-Hydroxy-3-(1H-imidazol-4-yl)propan-2-yl)-4-phenoxybenzenesulfonamide Hydrochloride (25e). To a $25 \mathrm{~mL}$ round-bottom flask, le $(3 \mathrm{mmol})$ was added and dissolved in DMF (10 mL). $\mathrm{Cs}_{2} \mathrm{CO}_{3}$ (1.5 eq.) and 24 (1.2 eq.) were then added, and the reaction was stirred for $24 \mathrm{~h}$ at room temperature. The reaction mixture was then washed with water, dried with $\mathrm{Na}_{2} \mathrm{SO}_{4}$, and evaporated under reduced pressure. The product was precipitated from the crude with dry $\mathrm{HCl} /$ eter solution and the filtered washed with $\mathrm{Et}_{2} \mathrm{O}$. White solid (51\%) $241-243^{\circ} \mathrm{C} .{ }^{1} \mathrm{H}-\mathrm{NMR}\left(400 \mathrm{MHz}, \mathrm{CD}_{3} \mathrm{OD}\right)$ $\delta$ 2.78-2.85 (m, 2H, H-3); 3.47-3.52 (m, 2H, H-1, H-2); 3.68$3.71(\mathrm{~m}, 1 \mathrm{H}, \mathrm{H}-1) ; \delta 7.02-7.10(\mathrm{~m}, 5 \mathrm{H}, \operatorname{aryl}) ; 7.39(\mathrm{~d}, J=$ $8.8 \mathrm{~Hz}, 2 \mathrm{H}$, aryl); 7.48 (s, $1 \mathrm{H}$, imidazole); 7.80 (d, $2 \mathrm{H}$, aryl); 8.85 (s, $1 \mathrm{H}$, imidazole). ${ }^{13} \mathrm{C}$ NMR $\left(100 \mathrm{MHz}, \mathrm{CD}_{3} \mathrm{OD}\right) \delta 28.4$ (C-3), 52.6 (C-1), 63.2 (C-3), 114.0, 117.8, 118.2, 120.10, 121.4,
129.2, 130.1, 133.2, 139.8, 151.1, 159.2 (aryl). ESI-MS calc for $\mathrm{C}_{18} \mathrm{H}_{20} \mathrm{ClN}_{3} \mathrm{O}_{4} \mathrm{~S} 2409.89$, found 409.91 .

\section{Molecular Modeling}

All calculations were performed on a DELL T5500 workstation, equipped with two Intel Xeon E5630 $2.53 \mathrm{GHz}$ processors.

All compounds were manually built in Maestro version 9.3.5, [35] exploiting the Built facility and minimized to a derivative convergence of $0.001 \mathrm{~kJ}^{-1} \mathrm{~mol}^{-1}$, using the Truncated Newton Conjugate Gradient (TNCG) minimization algorithm, the OPLS2005 force field, and the GB/SA water solvation model implemented in MacroModel version 9.9 [23].

Conformational searches, applying the mixed torsional/ low-mode sampling and the automatic setup protocol, were carried out on all minimized ligand structures to obtain the global minimum geometry of each molecule, to be used as the starting conformation for docking calculations with Glide, version $5.8[24,36,37]$.

Three-dimensional coordinates of MMP-1, -2, -8, and -9 were downloaded from the Brookhaven Protein Data Bank [38] (PBD ID: 1HFC, 1QIB, 1I76, and 1GKC, resp.). Each 3D structure was submitted to the Protein Preparation routine in Maestro that allows fixing of receptor structures, eliminating water molecules and possible ligands, fixing bond orders, adding hydrogen atoms, and ionizing charged residues. Hydrogen bond network is optimized, and for each structure, a brief relaxation was performed using an allatom constrained minimization carried out with the Impact Refinement module version 5.8 and the OPLS-2005 force field to reduce steric clashes that may exist in the original PDB structures. The minimization was terminated when the energy converged or the root mean square deviation (RMSD) reached a maximum cut-off of $0.30 \AA$.

Glide energy grid was generated using the crystallographic ligand of 1176 as the centre of the grid, after superimposing all MMPs structures under study. The size of the box was determined automatically on the basis of the ligand dimensions. The global minimum geometry of ligands was submitted to docking calculations in the previously prepared proteins. The van der Waals radii for nonpolar ligand atoms were scaled by a factor of 0.8 , thereby decreasing penalties for close contacts. Receptor atoms were not scaled. A first docking run was carried out applying the Standard Precision settings of Glide. Ten poses were saved and resubmitted to docking with the Extra Precision (XP) settings; [39] one pose was saved in this second run. The best ranking pose for each ligand in each protein was submitted to Liaison [29] to derive the scoring function applying the LIE method. Ligands and receptors structures were minimized in free and bound states through 1000 TNCG steps, allowing receptor residues $15 \mathrm{~A}$ far from the ligand to be freely relaxed. Implicit GB/SA solvent model was applied for solvation energy calculation.

The calculated $U_{\mathrm{vdW}}, U_{\text {ele }}$, and $U_{\text {cav }}$ parameters were correlated to experimental activity data using Strike [30] and the Multiple Linear Regression method, validating the model through leave-one-out (LOO) cross-validation analysis. 


\section{Conflict of Interests}

The authors do not have a direct financial relation with the commercial identity mentioned in their submitted paper that might lead to a conflict of interests for any of them.

\section{Acknowledgments}

The ESI/MS and NMR spectral data were provided by Centro di Ricerca Interdipartimentale di Analisi Strumentale, Università degli Studi di Napoli "Federico II." The assistance of the staff is gratefully appreciated. This work was supported by grant from MIUR-PRIN 2005.

\section{References}

[1] M. D. Sternlicht and Z. Werb, "How matrix metalloproteinases regulate cell behavior," Annual Review of Cell and Developmental Biology, vol. 17, pp. 463-516, 2001.

[2] H. Nagase and J. F. Woessner Jr, "Matrix metalloproteinases," The Journal of Biological Chemistry, vol. 274, no. 31, pp. 2149121494, 1999.

[3] C. Chang and Z. Werb, "The many faces of metalloproteases: cell growth, invasion, angiogenesis and metastasis," Trendsin Cell Biology, vol. 11, pp. S37-S43, 2001.

[4] C. Streuli, "Extracellular matrix remodelling and cellular differentiation," Current Opinion in Cell Biology, vol. 11, no. 5, pp. 634640, 1999.

[5] W. C. Parks, C. L. Wilson, and S. Y. López-Boado, "Matrix metalloproteinases as modulators of inflammation and innate immunity," Nature Reviews Immunology, vol. 4, no. 8, pp. 617629, 2004.

[6] M. Egeblad and Z. Werb, "New functions for the matrix metalloproteinases in cancer progression," Nature Reviews Cancer, vol. 2, no. 3, pp. 161-174, 2002.

[7] S. Zucker, C. Jian, and W. T. Chen, "Critical appraisal of the use of matrix metalloproteinase inhibitors in cancer treatment," Oncogene, vol. 19, no. 56, pp. 6642-6650, 2000.

[8] C. M. Overall and C. López-Otín, "Strategies for MMP inhibition in cancer: innovations for the post-trial era," Nature Reviews Cancer, vol. 2, pp. 657-672, 2002.

[9] M. Hidalgo and S. G. Eckhardt, "Development of matrix mettaloproteinase inhibitors in cancer therapy," Journalof the National Cancer Institute, vol. 93, no. 3, pp. 178-193, 2001.

[10] J. F. Fisher and S. Mobashery, "Recent advances in MMP inhibitor design," Cancer and Metastasis Reviews, vol. 25, no. 1, pp. 115-136, 2006.

[11] B. Davies, P. D. Brown, N. East, M. J. Crimmin, and F. R. Balkwill, "A synthetic matrix metalloproteinase inhibitor decreases tumor burden and prolongs survival of mice bearing human ovarian carcinoma xenografts," Cancer Research, vol. 53, pp. 2087-2091, 1993.

[12] X. Wang, X. Fu, P. D. Brown, M. J. Crimmin, and R. M. Hoffman, "Matrix metalloproteinase inhibitor BB-94 (batimastat) inhibits human colon tumor growth and spread in a patient-like orthotopic model in nude mice," Cancer Research, vol. 54, no. 17, pp. 4726-4728, 1994.

[13] A. H. Drummond, P. Beckett, P. D. Brown et al., "Preclinical and clinical studies of MMP inhibitors in cancer," Annals of the New York Academy of Sciences, vol. 878, pp. 228-235, 1999.
[14] L. M. Coussens, B. Fingleton, and L. M. Matrisian, "Matrix metalloproteinase inhibitors and cancer: trials and tribulations," Science, vol. 295, no. 5564, pp. 2387-2392, 2002.

[15] E. Breuer, J. Frant, and R. Reich, "Recent non-hydroxamate matrix metalloproteinase inhibitors," Expert Opinion on Therapeutic Patents, vol. 15, no. 3, pp. 253-269, 2005.

[16] D. T. Puerta and S. M. Cohen, "A bioinorganic perspective on matrix metalloproteinase inhibition," Current Topics in Medicinal Chemistry, vol. 4, no. 23, pp. 1551-1573, 2004.

[17] Puerta, D. T. Mongan, J. Ba, L. Tran, J. McCammon, and S. M. Cohen, "Potent, selective pyrone-based inhibitors of stromelysin-1," Journal of the American Chemical Society, vol. 127, pp. 14148-14149, 2005.

[18] F. Grams, H. Brandstetter, S. DAlò et al., "Pyrimidine-2,4,6Triones: a new effective and selective class of matrix metalloproteinase inhibitors," Biological Chemistry, vol. 382, pp. 1277-1285, 2001.

[19] M. T. Rubino, M. Agamennone, C. Campestre et al., "Cover picture: biphenyl sulfonylamino methyl bisphosphonic acids as inhibitors of matrix metalloproteinases and bone resorption," Chemmedchem, vol. 6, no. 7, p. 1133, 2011.

[20] J. W. Skiles, N. C. Gonnella, and A. Y. Jeng, "The design, structure, and clinical update of small molecular weight matrix metalloproteinase inhibitors," Current Medicinal Chemistry, vol. 11, no. 22, pp. 2911-2977, 2004.

[21] M. Whittaker, C. D. Floyd, P. Brown, and A. J. H. Gearing, "Design and therapeutic application of matrix metalloproteinase inhibitors," ChemicalReviews, vol. 99, no. 9, pp. 27352776, 1999.

[22] G. W. Kabalka, M. Varma, R. S. Varma, P. C. Srivastava, and F. F. Knapp Jr., "Tosylation of alcohols," Journal of Organic Chemistry, vol. 51, no. 12, pp. 2386-2388, 1986.

[23] P. Campiglia, I. Gomez-Monterrey, L. Longobardo, T. Lama, E. Novellino, and P. Grieco, "An efficient approach for monosulfide bridge formation in solid-phase peptide synthesis," Tetrahedron Letters, vol. 45, no. 7, pp. 1453-1456, 2004.

[24] C. K. Wada, J. H. Holms, M. L. Curtin et al., "Phenoxyphenyl sulfone N-formylhydroxylamines (Retrohydroxamates) as potent, selective, orally bioavailable matrix metalloproteinase inhibitors," Journal of Medicinal Chemistry, vol. 45, no. 1, pp. 219-232, 2002.

[25] C. M. Overall and O. Kleifeld, "Towards third generation matrix metalloproteinase inhibitors for cancer therapy," The British Journal of Cancer, vol. 94, no. 7, pp. 941-946, 2006.

[26] B. G. Rao, "Recent developments in the design of specific matrix metalloproteinase inhibitors aided by structural and computational studies," Current Pharmaceutical Design, vol. 11, no. 3, pp. 295-322, 2005.

[27] F. E. Jacobsen, J. A. Lewis, and S. M. Cohen, "The design of inhibitors for medicinally relevant metalloproteins," ChemMedChem, vol. 2, no. 2, pp. 152-171, 2007.

[28] P. Cuniasse, L. Devel, A. Makaritis et al., "Future challenges facing the development of specific active-site-directed synthetic inhibitors of MMPs," Biochimie, vol. 87, no. 3-4, pp. 393-402, 2005.

[29] A. Agrawal, D. Romero-Perez, J. A. Jacobsen, F. J. Villarreal, and S. M. Cohen, "Zinc-binding groups modulate selective inhibition of MMPs," ChemMedChem, vol. 3, no. 5, pp. 812-820, 2008.

[30] J. Åqvist, C. Medina, and J. E. Samuelsson, "A new method for predicting binding affinity in computer-aided drug design," Protein Engineering, vol. 7, no. 3, pp. 385-391, 1994. 
[31] T. Hansson and J. Åqvist, "Estimation of binding free energies for HIV proteinase inhibitors by molecular dynamics simulations," Protein Engineering, vol. 8, no. 11, pp. 1137-1144, 1995.

[32] C. M. Overall and O. Kleifeld, "Validating matrix metalloproteinases as drug targets and anti-targets for cancer therapy," Nature Reviews Cancer, vol. 6, no. 3, pp. 227-239, 2006.

[33] M. D. Martin and L. M. Matrisian, "The other side of MMPs: protective roles in tumor progression," Cancer and Metastasis Reviews, vol. 26, pp. 717-724, 2007.

[34] G. S. Butler and C. M. Overall, "Proteomic identification of multitasking proteins in unexpected locations complicates drug targeting," Nature Reviews Drug Discovery, vol. 8, no. 12, pp. 935-948, 2009.

[35] Maestro, Version 9. 3, MacroModel, Version 9. 9, Glide, Version 5. 8, Liaison, Version 5. 8, Strike, Version 2. 1, Schrödinger LLC, New York, NY, USA, 2012.

[36] T. A. Halgren, R. B. Murphy, R. A. Friesner et al., "Glide: a new approach for rapid, accurate docking and scoring. 2. Enrichment factors in database screening," Journal of Medicinal Chemistry, vol. 47, no. 7, pp. 1750-1759, 2004.

[37] R. A. Friesner, J. L. Banks, R. B. Murphy et al., "Glide: a new approach for rapid, accurate docking and scoring. 1. Method and assessment of docking accuracy," Journal of Medicinal Chemistry, vol. 47, no. 7, pp. 1739-1749, 2004.

[38] H. M. Berman, J. Westbrook, Z. Feng, G. Gilliland, T. N. Bhat et al., "The protein data bank," Nucleic Acids Research, vol. 28, no. 1, pp. 235-242, 2000.

[39] R. A. Friesner, R. B. Murphy, M. P. Repasky et al., "Extra precision glide: docking and scoring incorporating a model of hydrophobic enclosure for protein-ligand complexes," Journal of Medicinal Chemistry, vol. 49, no. 21, pp. 6177-6196. 

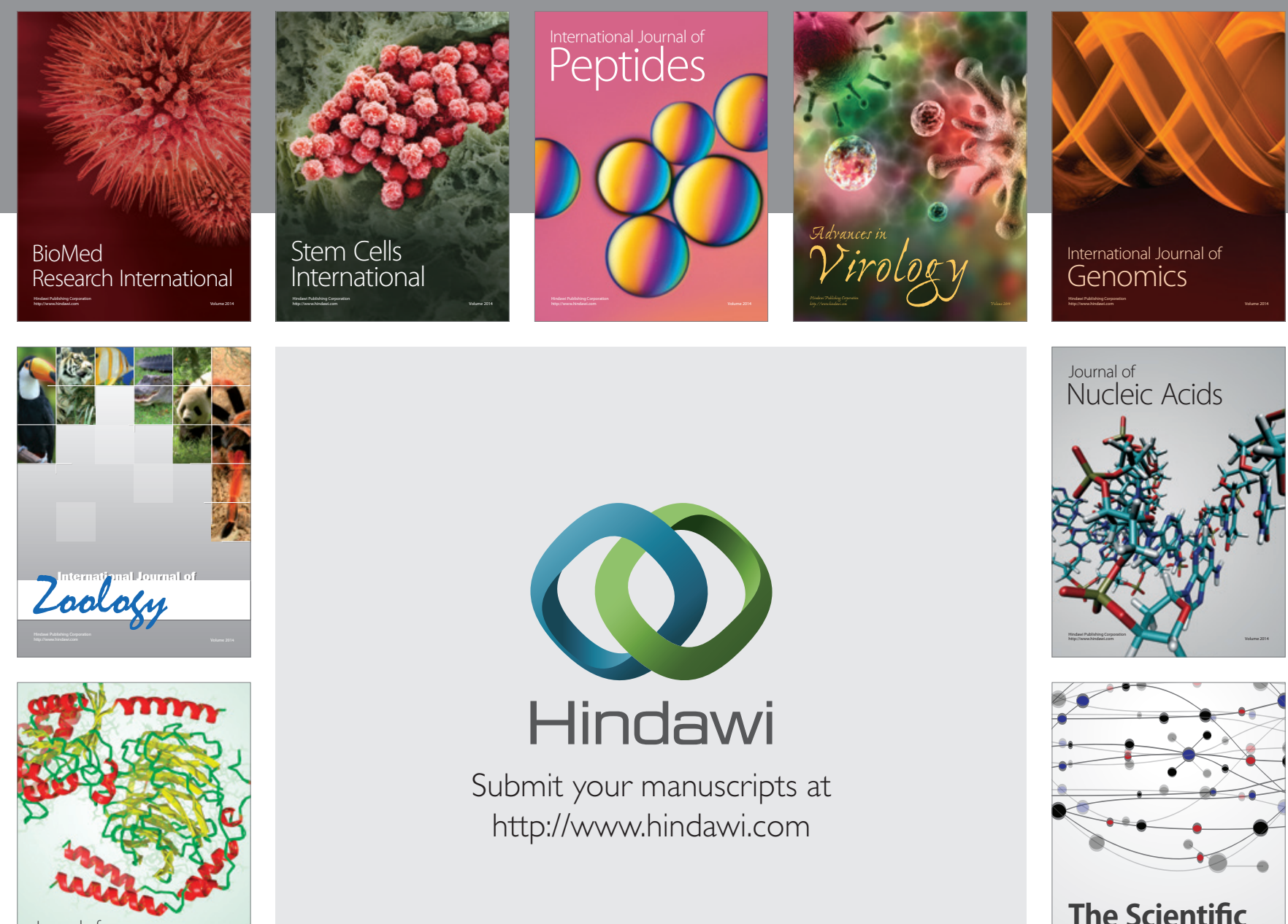

Submit your manuscripts at

http://www.hindawi.com

Journal of
Signal Transduction
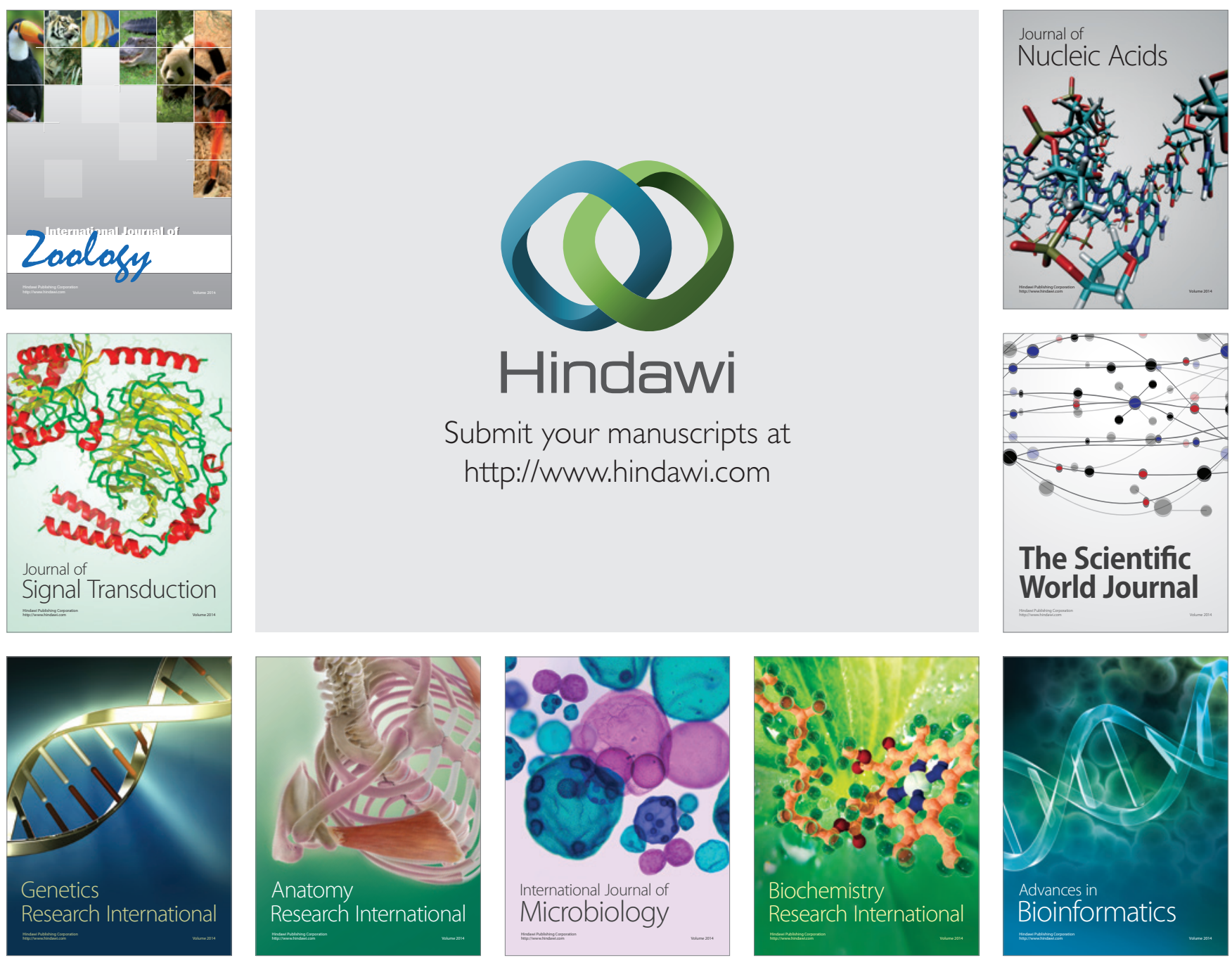

The Scientific World Journal
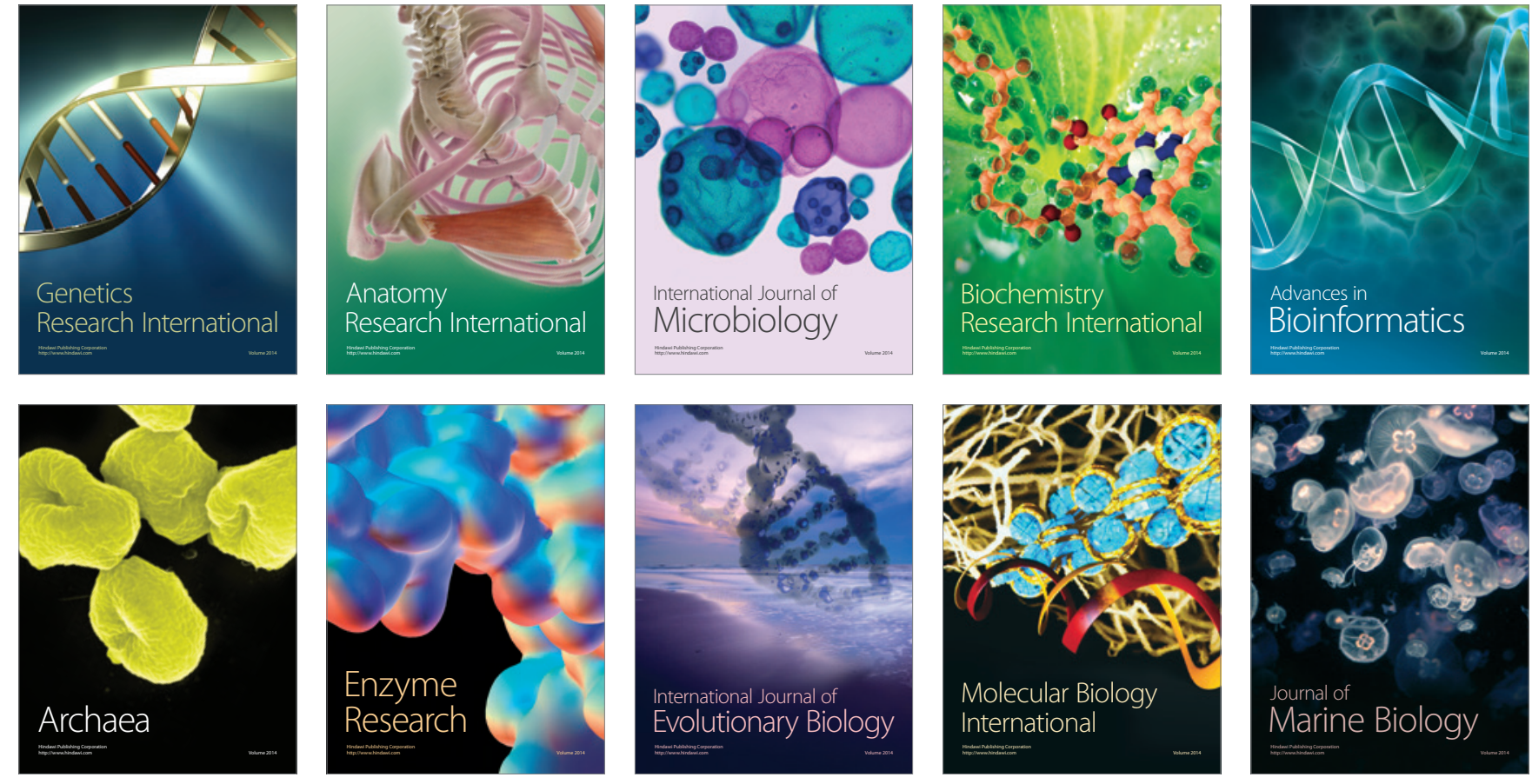